Bull. Fac. Agric., Cairo Univ., 68: 183-195 (2017).

\title{
EVALUATION OF POMEGRANATE PEEL AND ITS BEVERAGES AS ANTIBACTERIAL AND ANTICANCER AGENT
}

(Received: 26.7.2017)

\author{
By \\ E. A. El-Kholany \\ Department of Special Foods, Food Technology Research Institute, \\ Agricultural Research Center, Giza, Egypt
}

\begin{abstract}
Pomegranate (Punica granatum) peel is an important source of bioactive compounds against a varied number of maladies. The main target of the present investigation was to determine the chemical composition, total phenols, flavonoids, and antioxidant activity of pomegranate peel (PGP) as well as the potential biological activities of aqueous peel extract. Antibacterial activity was measured using $20 \%$ and $40 \%$ aqueous extracts of pomegranate peel (PGPa) using well diffusion plate method against Helicobacter pylori and Campylobacter jujini which are the most common bacteria causing gastric infections worldwide. Pomegranate peel showed high content of total phenols (198.33 mg Gallic acid/g) and flavonoids, (46.86 mg Quercetin/g) with strong antioxidant activity (95.96\%). Inhibition percentages of $40 \%$ aqueous extracts were 79 and $45.6 \%$ for Campylobacter jujini and Helicobacter pylori at 100 $\mu \mathrm{l} /$ well, respectively. Thus, minimum inhibitory concentration (MIC) of aqueous extract was 125 and 250 $\mu \mathrm{g} / \mathrm{ml}$ for Campylobacter jujini and Helicobacter pylori, respectively. Morphological studies by scanning electron microscopy using $20 \%$ of aqueous pomegranate peel (PGPa) showed segmentation, elongation and enlargement of Campylobacter jujini bacterial cells. Antitumor activity of pomegranate peel against intestinal cancer cell lines (Caco-2 cells) was shown at various concentrations of extracts with $\mathrm{IC}_{50} 120$ $\pm 1.30 \mu \mathrm{g} / \mathrm{ml}$. Sensory evaluation of pomegranate peel beverage at series concentrations from 0.5 to 2.5 $\%$ was done to evaluate the impact of its application in the beverage production. This study suggests the possibility that PGP beverage can be used for dietary therapy to treat microbial infections.
\end{abstract}

Key words: Pomegranate peel, pomegranate beverages, Helicobacter pylori, Campylobacter jujini, Scanning electron microscopy, antitumor activity.

\section{INTRODUCTION}

At the present time, fruit wastes and by products are disposed often at a cost to the manufacturer. Therefore, using these wastes in a suitable form as a source of polyphenols may be of considerable economic benefit to food processors. One of these plants is Punica granatum (Punicaceae), commonly called pomegranate, which is an edible fruit cultivated in Mediterranean countries. Pomegranate peel (PGP) contributes about $50 \%$ of the whole weight of fruit, which contains bioactive compounds such as phenolic components, tannins, pro-anthocyanidins components, flavonoids ( $\mathrm{Li}$ et al., 2006) and complex polysaccharides (Jahfar et al., 2003). $P$. granatum has been widely used as a traditional medicine in America, Asia, Africa and Europe for the treatment of different types of diseases, to treat gastrointestinal diseases, parasitic diseases, and has anti-oxidant properties (Rabah et al., 2015). The anti-inflammatory, antioxidant, and antimicrobial characteristics of PG could be advantageous in the treatment of stomach ulcers. Braga et al. (2005) showed that PG extract can be a potential antibacterial therapeutic agent due to its ability to inhibit enterotoxin.

Foodborne diseases are a serious and global problem, mainly observed in infants, young children, the elderly and the immunocompromised. Due to lack of side effects compared to synthetic (antibiotic) drugs, new trends in treatment have relied on plants for medication. From ancient 
times, plants have been proved to be a powerful therapeutic agents for the treatment of various human diseases. It has been observed that pomegranate, exhibited strong antimicrobial activity against some groups of $\mathrm{G}^{+} \mathrm{ve}$ and $\mathrm{G}^{-} \mathrm{ve}$ pathogens (Kossah et al., 2011). Substantial portion of the cancer burden worldwide is attributable to microbial pathogens. In the case of bacterial infection, several events (e.g. the establishment of chronic inflammation, as well as the production of genotoxins or bacterial products that interfere with regulation of cell cycle progression and apoptosis), in association with host genetic factors, may contribute to the acquisition of the mutter phenotype (Guerra et al., 2011). Gastrointestinal diseases affect most people at some stage in their life. Two major causative factors are Helicobacter pylori and Campylobacter jejuni and a major predisposing factor for peptic ulcer disease (PUD) and gastric carcinoma (Kusters et al., 2006). All Campylobacter jejuni species produce a genotoxin, which induces DNA double strand breaks, could lead to an increased risk of cancer especially in the gastro-intestinal tract (Brauner et al., 2010). In this regard, using of pomegranate has a considerable anticarcinogenic effect which is mainly due to ellagic acid, that induces apoptosis in human colon cancer cell line via the intrinsic pathway with release of cytochrome $\mathrm{C}$ into the cytosol (Kasimsetty et al., 2010).

Based on these facts, the aim target of the present study was to investigate the chemical composition, bioactive compounds and antioxidant activity of waste from pomegranate peel concerning the application of natural antimicrobials. Also, to examine the beverage from PGP to be used in the treatment of gastrointestinal microbial infections.

\section{MATERIALS AND METHODS}

2.1. Materials

\subsubsection{Pomegranate peel}

The fresh and mature pomegranate (Punica granatum L.) as a source of pomegranate peel was obtained from the Horticultural Research Institute, Agriculture Research Center, Giza, Egypt.

\subsubsection{Chemicals and reagent}

All chemicals, including Folin - Ciocaltea's reagent, DPPH (1, 1-Diphenyl-2-picryl-hydrazyl), standards of phenolic, flavonoids and all others reagents used in the study (analytical grade) were purchased from Sigma-Aldrich (St. Louis, MO, USA).

\subsubsection{Bacterial culture}

The $H$. pylori bacterial strain (ATCC 43504) and the $C$. jejuni bacterial strain (ATCC 700819) were obtained from Regional Center of Mycology and Biotechnology, (RCMB) Cairo, Egypt and pre-cultured on agar plates containing brain heart infusion (Oxoid) supplemented with 5\% (v/v) sterile horse blood (Oxoid). The plates were incubated at $37{ }^{\circ} \mathrm{C}$ in an incubator under microaerophilic conditions for $24-48 \mathrm{~h}$.

\subsubsection{Cell lines and cell cultures}

The human intestinal cancer cell lines (Caco-2 cells) were obtained from RCMB Cairo, Egypt.

2.2.1. Technological method

\subsubsection{Preparation of Pomegranate peel Powder (PGP)}

Pomegranate peels were washed and spread as a thin layer in the dryer after stabilizing by heated air at the desired temperature $50{ }^{\circ} \mathrm{C}$. The peels were crushed using pestle and mortar followed by high speed laboratory blender, then sieved with 20-30 mesh to obtain finely divided powder (Senadeera, et al., 2003).

\subsubsection{Preparation of Pomegranate aqueous extracts (PGPa)}

Pomegranate peels powder PGP at concentration 20 and $40 \mathrm{gm}$ were soaked in 100 $\mathrm{ml}$ boiling distilled water then stored in a vacuum flask for $12 \mathrm{~h}$. The crude extract was filtered through muslin followed by Whatman No. 1 filter paper the filtrate was made up to $100 \mathrm{ml}$ using distilled water and transferred to clean and dried bottle, and stored at $4{ }^{\circ} \mathrm{C}$ until use (Vaishnavi et al., 2007).

\subsubsection{Preparation of Pomegranate peel beverage}

The hot beverage of pomegranate peel was prepared at different concentrations by mixing pomegranate peel powder at $(0.5,1.0,1.5,2.0$ and $2.5 \mathrm{gm}$ ) with $100 \mathrm{ml}$ water, then $5 \mathrm{~g}$ of sugar was added.

\subsubsection{Chemical methods}

\subsubsection{Chemical Composition of pomegranate peel Powder}

Moisture, crude protein, ash, crude fat and dietary fiber were determined by the standard 
procedures of the A.O.A.C (2005). Carbohydrates were calculated by difference.

\subsubsection{Determination of total phenolic compounds}

The total phenolic compounds of pomegranate peels and its beverage were determined calorimetrically using Folin-Ciocalteu reagent according to the method described by Singleton $e t$ al. (1999). The absorbance of the mixture was measured at $725 \mathrm{~nm}$ against blank using spectrophotometer (Jenway 6705 uv /vis). Gallic acid was used as a standard.

\subsubsection{Determination of total flavonoids}

Total flavonoids of pomegranate peels and its beverage were determined according to the methods of Zhishen et al. (1999). Previous extract $(0.4 \mathrm{ml})$ was added to $4 \mathrm{ml}$ of $\mathrm{H}_{2} \mathrm{O}$. Then $0.3 \mathrm{ml}$ of $5 \% \mathrm{NaNO}_{2}$ was added. After five min, $0.3 \mathrm{ml}$ of $10 \% \mathrm{AlCl}_{3}$ was added. After six min, $2 \mathrm{ml}$ of $1 \mathrm{M}$ $\mathrm{NaOH}$ was added and the total volume was made up to $10 \mathrm{ml}$ with distilled water. The color was measured at $510 \mathrm{~nm}$ against a blank reagent using spectrophotometer (Jenway 6705 uv /vis). Quercetin was used as standard.

\subsubsection{Determination of antioxidant activity}

The antioxidant activity of pomegranate peels and its beverage were determined based on the radical scavenging ability in reacting with a stable DPPH (1, 1-Diphenyl-2-picryl-hydrazyl) free radical according to Brand-Williams et al. (1995). DPPH $(2.4 \mathrm{mg})$ in $100 \mathrm{ml}$ methanol was prepared and $3.9 \mathrm{ml}$ of this solution was added to $0.1 \mathrm{ml}$ of sample extract. The mixture was shaken vigorously and allowed to stand at room temperature for $30 \mathrm{~min}$ in the dark. Then the absorbance was measured at $515 \mathrm{~nm}$ using spectrophotometer (Jenway $6705 \mathrm{uv} / \mathrm{vis}$ ). The radical scavenging percentage was calculated by the following equation:

Scavenging activity $(\%)=1-$ (absorbance of extract /absorbance of control) $\times 100 \%$

\subsubsection{Identification of phenolic acids and flavonoids compounds}

Phenolic and flavonoid compounds were fractionated using HPLC according to the method of Goupy et al. (1999) and Mattila et al. (2000). The methanolic extract of pomegranate peels powder and its beverage (2\%) were injected into Agilent HPLC (Series 1200) 5HC-C18, $250 \mathrm{x}$ $4.6 \mathrm{~mm}$ and ultraviolet detector which adjusted at $280 \mathrm{~nm}$ for phenolic acids and $330 \mathrm{~nm}$ for flavonoids. Gradient separation was carried out with methanol and acetonitrile as a mobile phase at flow rate of $1 \mathrm{ml} / \mathrm{min}$. Column temperature was maintained at $35^{\circ} \mathrm{C}$. The fractionated phenolic and flavonoids were identified comparison of its retention time compared with those of automatic areas.

\subsubsection{Evaluation of antitumor activity}

Pomegranate peels was tested for any cytotoxic effect against human intestinal tumor cell line (Caco-2 cells). The cell suspension was prepared in complete growth Roswell Park Memorial Institute medium (RPMI) supplemented with 50 $\mu \mathrm{g} / \mathrm{ml}$ gentamycin. The aliquots of $100 \mu \mathrm{l}$ of cell suspension $1 \times 10^{5}$ were added to each well on a 96-well tissue culture plate. The blank wells contained complete RPMI medium in place of cell suspension. The cells were incubated for $24 \mathrm{~h}$ at $37{ }^{\circ} \mathrm{C}$ in a humidified incubator with $5 \% \mathrm{CO}_{2}$. After the formation of a complete monolayer cell sheet in each well of the plate, PGP was added. Serial two- fold dilutions of the sample ranging from $7.81 \mu \mathrm{g} / \mathrm{ml}$ to $500 \mu \mathrm{g} / \mathrm{ml}$ was added into a 96- well tissue culture plate using multi channel pipette (eppendorff, Germany). After treatment $(24 \mathrm{~h})$, the culture supernatant was replaced by fresh medium. Then the cells in each well were incubated at $37{ }^{\circ} \mathrm{C}$ with $100 \mu$ l of MTT solution (5 $\mathrm{mg} / \mathrm{ml}$ ) for $4 \mathrm{~h}$. After the end of incubation, the MTT solution was removed, then $100 \mu \mathrm{l}$ of DMSO was added to each well. The absorbance was detected at $570 \mathrm{~nm}$ using a microplate ELISA reader (SunRise TECAN, Inc, USA). The absorbance of untreated cells was considered as $100 \%$. The results were determined by three independent experiments .

Data Calculations: The percentage of cell viability was calculated using the Microsoft Excel $^{\circledR}$; according to the following equation:

$\%$ of cell viability $=[1-(\mathrm{ODt} / \mathrm{ODc})] \times 100 \%$, where ODt is the mean optical density of wells treated with the tested compound and ODc is the mean optical density of untreated cells. Cisplatin was used as positive control. The absorbance is proportional to the number of surviving cells in the culture plate. The tested sample was also compared using the $\mathrm{IC}_{50}$ value, i.e., the concentration of an individual compound leading to $50 \%$ cell death that was estimated from graphical plots of viable cells vs compound concentrations. 


\subsubsection{Microbiological methods}

\subsubsection{Antibacterial activity}

The antibacterial activity of pomegranate peel and its aqueous extract PGPa against $H$. pylori (ATCC 43504) and C. jejuni (ATCC 700819) strains were carried out by well agar diffusion method. Diluted bacterial culture $\left(100 \mu 1,10^{6}\right.$ $\mathrm{CFU} / \mathrm{ml}$ ) of the bacterial strains was spread on the surface of BHI (Brain Heart Infusion) medium. Aqueous extract PGPa was used at 25, 50, 75, and $100 \mu \mathrm{l} / \mathrm{ml}$ of each well and distilled water as a negative control. After incubation at $37{ }^{\circ} \mathrm{C}$ in a microaerophilic atmosphere for $24 \mathrm{~h}$. The diameters of the growth-free zones around the disks were measured and subtracted from the diameter of well diffusion, giving the sizes of the inhibition zones beyond the well (Valgas et al., 2007).

\subsubsection{Minimum inhibitory concentration (MIC)}

The minimum inhibitory concentrations (MIC) of pomegranate peel extracted $\mathrm{PGPa}$ as antibacterial activity against Campylobacter juijuni and $H$. pylori were determined. The minimum inhibitory concentrations (MIC) were determined by dilution method (Abhijeet et al., 2010), using two-fold serial dilution of the purified PGPa starting with the concentrations of the aqueous extract achieved was the following 500, 250 ,125, 62.5, 31.25, 16, 8, 4, 2, $1 \mu \mathrm{g} / \mathrm{ml}$. respectively. Petri dishes containing $20 \mathrm{ml}$ of BHI medium were seeded with bacterial suspension. Wells were made on agar using a sterile cork porer. Into the wells, $100 \mu 1$ of aqueous extracts were added and incubated at $37{ }^{\circ} \mathrm{C}$ under microaerophilic conditions for $48 \mathrm{~h}$. Two petri dishes were prepared for each antibacterial agent. The lowest concentration of the aqueous extract of pomegranate peel that produced visible inhibition zone around the well was regarded as MIC.

\subsubsection{Scanning electron microscopy}

Sample (Campylobacter jujini cells treated with $20 \%$ of PGPa) was fixed by gluteraldhyed $2.5 \%$ and dehydrated by serial dilution of ethanol with agitation using automatic tissue process (Leica EMTP, Leica Microsystem; Austria), then samples were dried using $\mathrm{Co}_{2}$ critical point dryer (Model: Audosamdri-185, Tousimis; Rockville, Maryland ,USA). Samples were coated by gold sputter coater (SPI-Modeule, USA). The samples were observed by scanning electron microscopy (Model: JSM-55500LV; JEOL LTD- Japan ) by using high vaccum mode at the Regional Center of Mycology and Biotechnology, (RCMB) Cairo, Egypt.

\subsubsection{Sensory evaluation}

The hot beverage extract of the pomegranate peel was prepared at different concentrations by soaking pomegranate peel powder $(0.5,1.0,1.5$, 2.0 and $2.5 \mathrm{~g}) 100 \mathrm{ml}$ water, then $5 \mathrm{~g}$ of sugar was added .The evaluation was carried out by 10 trained panelists of Special Food and Nutrition, FTRI, ARC, Giza, Egypt according to the method of Sensory Evaluation of Mirghani et al., (2012).

\subsubsection{Statistical analysis}

The data of the present study were subjected to analysis of variance and the Fisher's least significant difference test, SAS (1996) in order to compare the mean values of the investigated parameters at significance levels of $\mathrm{P} \geq 0.05$.

\section{RESULTS AND DISCUSSION}

\subsection{Chemical composition, total phenol, total flavonoids and antioxidant activity}

Chemical composition, total phenol, flavonoids and antioxidant activity of pomegranate peel powder (PGP) are presented in Table (1). Results indicated that the pomegranate peel powder (PGP) contained high amount of fiber and carbohydrate amounted in (15.94 and $68.86 \%)$, respectively. Moreover, low protein content was found in PGP $(4.35 \%)$. These results are in agreement with Sayed-Ahmed (2014) who reported that pomegranate peel (PGP) had a high content of fiber and carbohydrate.

It could be noticed that PGP had high content of total phenolic and total flavonoids (Table 1). In addition, high free radical scavenging activity is recorded in peels $95.96 \%$. In this respect, Singh and Immanuel (2014) stated that PGP is considered as a good source of bioactive compounds due to the higher content of polyphenols and flavonoids. The use of plants for treating various diseases including food born disease is used in many countries under the name of Folk medicine. The use of plants for curing diseases was important as it is already proven by seeing the problems associated with synthetic antibiotics (Khan and Hanee, 2011). 
Table (1): Chemical composition of pomegranate peel (dry weight).

\begin{tabular}{|l|c|}
\hline Constituents & Pomegranate peel (PGP) \\
\hline Protein (\%) & $4.35 \pm 0.29$ \\
\hline Oil (\%) & $4.16 \pm 0.38$ \\
\hline Ash (\%) & $\mathbf{5 . 6 9} \pm 0.35$ \\
\hline Fiber (\%) & $\mathbf{1 5 . 9 4 \pm 0 . 9 7}$ \\
\hline Carbohydrate (\%) & $\mathbf{6 8 . 8 6} \pm \mathbf{1 . 2 5}$ \\
\hline Total phenol ( mg GAE/gm) & $\mathbf{1 9 8 . 3 3} \pm 2.51$ \\
\hline Total Flavonoid (mg Que/gm) & $\mathbf{4 6 . 6 3 \pm 1 . 9 6}$ \\
\hline Antioxidant activity (\%) & $\mathbf{9 5 . 9 6} \pm 0.21$ \\
\hline
\end{tabular}

Values are mean of three replicates \pm SD.

\subsection{Antibacterial activity of pomegranate peel aqueous extract (PGPa) against Campylobacter jujini and $H$. pylori.}

Results in Table (2) showed the effect of pomegranate peel aqueous extract on human bacterial pathogens Campylobacter jujini and $H$. pylori which are the most common cause of gastric infections worldwide. Two different concentrations of aqueous extract $(20 \%$ and $40 \%$ w/v) were used. Because $20 \%$ optimum conc. which have antibacterial activity against Campylobacter jujini and H. pylori. For each concentration series of dilutions were used i.e. 25, 50, 75 and $100 \mu \mathrm{l} / \mathrm{ml}$. The results indicated that increasing the concentration of extract led an to increasing percentage of inhibition to $79 \%$ against Campylobacter jujini and $45.6 \%$ against H.pylori at concentration of $100 \mu \mathrm{l} / \mathrm{ml}$ of pomegranate peel aqueous extract for $(40 \%, \mathrm{w} / \mathrm{v})$. The minimum inhibitory concentration of PGPa was 125 and $250 \mu \mathrm{g} / \mathrm{ml}$ for Campylobacter jujini and $H$. pylori, respectively. Meanwhile, the level of resistance to amoxicillin $(30 \mu \mathrm{g} / \mathrm{ml})$ among both C. jejuni and H.pylori was 35 and $20 \%$, respectively.

Our finding indicates that the antimicrobial of PGPa showed higher effect when compared with Amoxicillin by using $20 \%$ extract the inhibition percent by about $54 \%$ and $43 \%$ respectively with Campylobacter and H.pylori. While $40 \%$ extract showed inhibitory effects by about $79 \%$ and $45.6 \%$ resensitivity against selected strain. These result may be attributed to the high content of phytochemical and phenolic compounds in pomegranate peels hot aqueous extract.

Our data agree with Moghaddam (2011) which showed the pomegranate rind extracts had highly inhibitory activity against $H$. pylori. Pomegranate peels are considered waste parts or by products obtained during juice processing and characterized by the significant presence of polyphenols such as ellagitannins, ellagic acid, gallic acid and flavonoids, associated with biological properties

Table (2): Antibacterial activity of pomegranate peel (PGP) aqueous extract against Campylobacter jujini and H.pylori

\begin{tabular}{|c|c|c|c|c|}
\hline \multirow{3}{*}{$\begin{array}{c}\text { Concentration } \\
\mu \mathrm{l} / \mathrm{ml}\end{array}$} & \multicolumn{4}{|c|}{ Inhibition \% } \\
\hline & \multicolumn{2}{|c|}{ Campylobacter jujini } & \multicolumn{2}{|c|}{ H.pylori } \\
\hline & $20 \%$ & $40 \%$ & $20 \%$ & $40 \%$ \\
\hline 25 & 14 & 19 & 7.6 & 11.4 \\
\hline 50 & 27 & 47.5 & 19 & 21.6 \\
\hline 75 & 42 & 66 & 32.5 & 31.3 \\
\hline 100 & 54 & 79 & 43 & 45.6 \\
\hline MIC at $20 \%(\mu \mathrm{g} / \mathrm{ml})$ & \multicolumn{2}{|c|}{125} & \multicolumn{2}{|c|}{250} \\
\hline (AMC) amoxicillin $(30 \mu \mathrm{g} / \mathrm{ml})$ & \multicolumn{2}{|c|}{35} & \multicolumn{2}{|c|}{20} \\
\hline
\end{tabular}


such as antioxidant and antimicrobial agents. Sun Hee et al., (2013), confirmed the inhibitory effects of pomegranate peel aqueous extracts on different bacterial isolates may be referred to the effect of flavonoids (e.g:7-O-butylnaringenin). Additionally, some phenolic compounds possess antimicrobial activities against various pathogenic bacteria, including C. jejuni (Klancnik et al., 2012).

\subsection{Effect of pomegranate peel aqueous extract} (20\%) on Campylobacter jujini morphology by using SEM.

Scanning electron microscopy (SEM) was used to further investigate the mechanisms by which pomegranate peel aqueous extract $\mathrm{PGPa}$ at concentration $20 \%$ which have optimum concentration antibacterial activity against target organism $(C$. jejuni) cells. The SEM image in Fig. (1 A and B) illustrates untreated cells, meanwhile Fig. (1 C, E and D) illustrates treated cells with $20 \%$ of pomegranate peel aqueous extract (PGPa). The Spiral-shape of $C$. jejuni cells exhibits a dramatic change from spiral to coccoid forms after treatment with PGPa. The SEM image in Fig. (1 $\mathrm{C}, \mathrm{E}$ and D) illustrates the dominance of coccoid forms in treated cells and shows the formation of irregular cell surfaces as the cells showed rough surface.

These coccoid cells remained intact and possessed sheathed polar flagella. Also, the treated cells exposed pore formation and local rupture in cell membranes may be due to the presence of phenolic compounds. Metamorphous cells of broken cell walls. The obtained data are in agreement with Borges et al. (2013). Also, He and chen (2010) reported a similar transformation in morphology when $C$. jejuni cells were exposed to different environmental stresses, including oxidative stress.

The present results indicate that the mechanisms of detectable cell damages might be depending on the presence of different kinds of flavonoids. The synergistic antimicrobial activity of phenolic compounds is associated with the alteration in membrane permeability and antibiotic accumulation in $C$. jejuni.
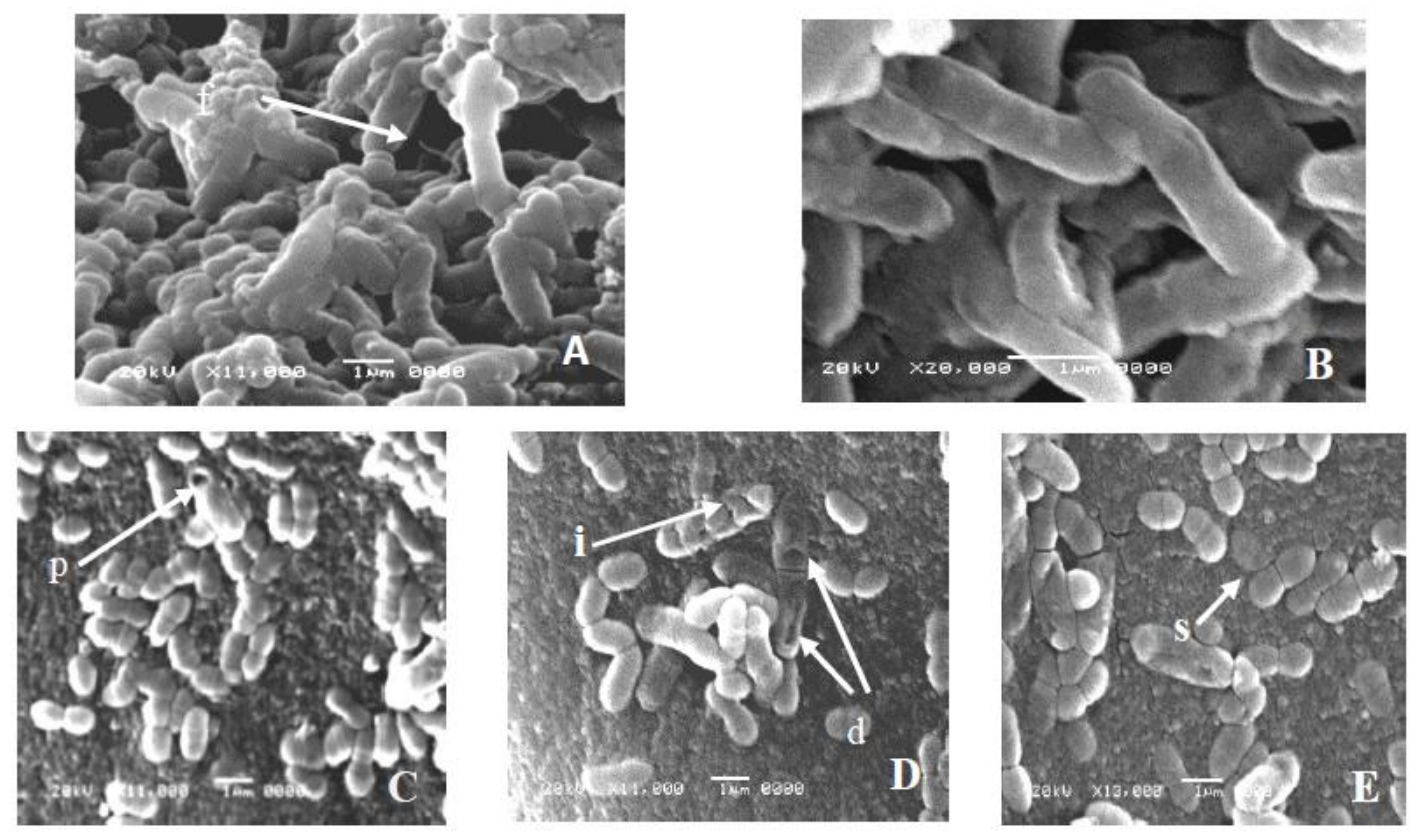

Fig. (1): SEM micrographs of Campylobacter jujini untreated with (PGP) pomegranate peel extract. (A, B) control, (C, D and E) treated with $20 \%$ aqueous extract (PGPa): (f) flagella, (p) pore formation, (i) irregular shape, (d) damage. 
In this context, Borges et al. (2013) reported that gallic acid relatively at high concentrations i.e., $>100 \mu \mathrm{g} \mathrm{ml}^{-1}$ increases membrane permeability in Gram-negative and positive bacteria, such as E. coli, Pseudomonas aeruginosa, and Listeria monocytogenes. Similar results were obtained by Sun Hee et al. (2013) who tested the antimicrobial effects of flavonoid on H. pylori. Generally, PGPa extract possess the strongest antibacterial properties against $C$. jejuni due to their high content of phenolic and flavonoid compounds.

\subsection{Evaluation of the antitumor activity.}

Effect of pomegranate peel aqueous extract (PGPa) against human intestinal tumor cell line (Caco-2 cells) was evaluated. Cytotoxicity affecting the Caco-2 cell line provides preliminary information about toxicity on intestinal cancer cells. The current results indicating that increasing the concentration of extract affect cell lines in the range of from 125 to $500 \mu \mathrm{g} / \mathrm{ml}$ leads to decrease cell population in the cell lines. Results illustrated in Table (3) clear that (PGPa) exhibited high inhibitory activity even at low concentrations. As the inhibitory activity of (PGPa) at $250 \mu \mathrm{g} / \mathrm{ml}$ reached $62.19 \%$ (Caco-2). By increasing the concentration to $500 \mu \mathrm{g} / \mathrm{ml}$ the inhibitory activity
Table (3): Evaluation of antitumor Activity of pomegranate peel $(\mu \mathrm{g} / \mathrm{ml})$ against Caco-2 cell line.

\begin{tabular}{|l|c|}
\hline Concentration $(\boldsymbol{\mu g} / \mathrm{ml})$ & Inhibitory $\%$ \\
\hline 500 & $70.25 \pm 1.39$ \\
\hline 250 & $62.19 \pm 1.98$ \\
\hline 125 & $51.48 \pm 2.36$ \\
\hline 62.5 & $34.62 \pm 3.14$ \\
\hline 31.25 & $25.8 \pm 0.38$ \\
\hline 15.6 & $17.55 \pm 0.17$ \\
\hline 7.8 & $8.28 \pm 0.36$ \\
\hline 3.9 & $3.11 \pm 0.13$ \\
\hline 0 & 0 \\
\hline${ }^{*} C_{50}$ & $120 \pm 1.30$ \\
\hline
\end{tabular}

" $\mathrm{IC}_{50}$ : value of the concentration an individual compound leading to $50 \%$ cell death

reached $70.25 \%$. In the present study, the anticancer activity of aqueous peel extract of pomegranate against Caco-2 cell line revealed growth inhibition starting at a concentration of $62.5 \mu \mathrm{g} / \mathrm{ml}$ and $\mathrm{IC}_{50} 120 \pm 1.30$.

Fig. 2 ( $a$ and $b$ ) illustrated the morphological changes of Caco- 2 cells untrated and treated tumer cell with PGPa clearly observed. The untreated

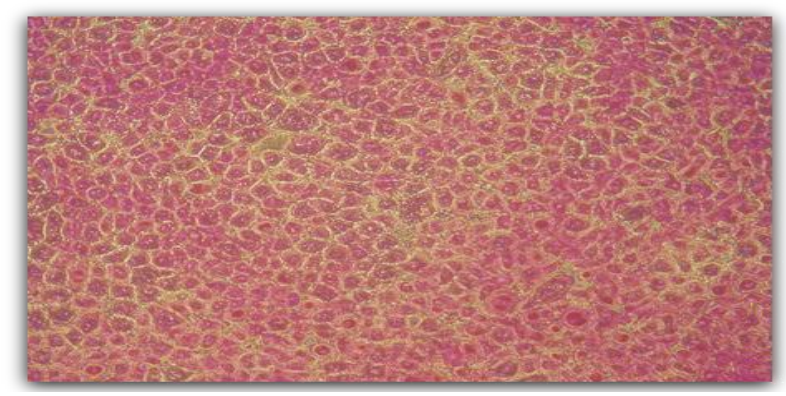

(a)Untreated cells

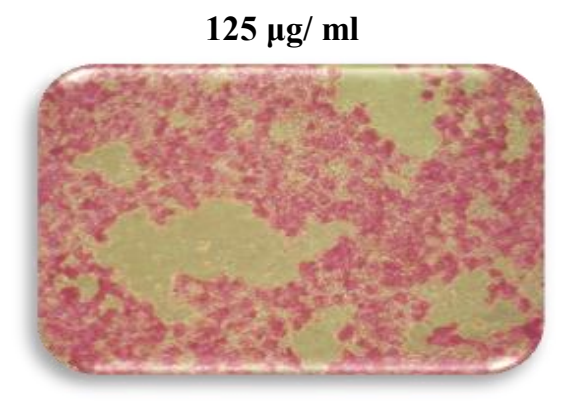

$250 \mu \mathrm{g} / \mathrm{ml}$
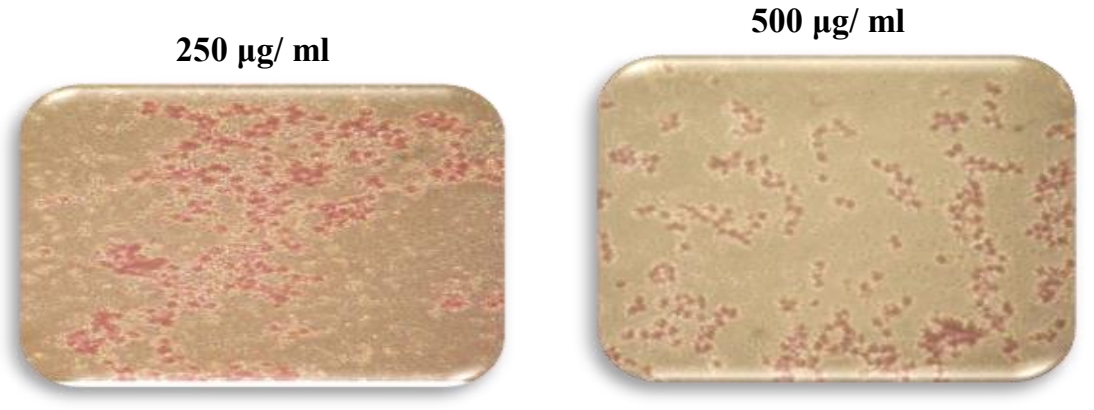

(b) Treated cells

Fig. (2): Effect of PGP on carcinoma cell line (Caco-2): (a) untreated cell; (b) treated cell of different concentration of PGP. 
tumer cells showed adherent growth and completely homogenous layer a regular shape (Fig. 2a), meanwhile (Fig. 2b) the tumor cell was clearly decreased as a result of treatment with different concentration.

In agreement with that of Rather et al. (2010) who found that the anticancer activity of extract from pomegranate peel against cell lines caused growth inhibition at a concentration $50 \mathrm{ug} / \mathrm{ml}$. While Larrosa et al., (2006) showed that pomegranate treated Caco-2 cells arrested in the $S$ phase of the cell cycle, down-regulation of cyclins $\mathrm{A}$ and $\mathrm{B} 1$ and upregulation of cyclin $\mathrm{E}$.

Vicinanza et al. (2013), indicated that both ellagic acid and urolithin A contribute to the mechanism of anticancer action of pomegranate products, however, urolithin was less effective in inhibiting cancer cell proliferation. While Sadik and Asker (2014) tested the extracts of Punica granatum for their antitumor activity against Ehrlich ascites carcinoma cells (EACC) and found that the viability of EACC was greatly increased by water extract followed by ethanol and methanol extracts. This effect may be due to the interaction between extract compounds and proteins located on the membrane of cells.

\subsection{Sensory evaluation of pomegranate peel beverage.}

The results (Table 4) show that beverage samples from pomegranate peel powder concentration up to $2 \%$ had high scores in all their sensory attributes. However, taste score decreased significantly at $2.5 \%$ concentration level. This might be related to the slight bitterness of taste due to increasing polyphenols at the highest level of pomegranate peel powder. Data of taste, flavor, odor and overall acceptability showed no significant difference between beverage samples prepared at concentration $1,1.5$ and $2 \%$. Beverage samples prepared with pomegranate peel powder had high total score except in case of $2.5 \%$ concentration level which significantly decreased than the other concentration.

\subsection{Bioactive compound content in pomegranate peel beverage}

The total amount of phenols, flavonoids content as bioactive compound and antioxidant activity of pomegranate peel beverage are

illustrated in Fig (3). It could be noticed that the amount of phenols and flavonoids of PGP beverage were increased by increasing the amount of pomegranate peel powder. Also, it could be attributed to the higher total phenol and flavonoid contents of pomegranate peel beverage prepared at $2 \%$ (w/v) with recoded 19.208 and $17.55 \mathrm{mg} / \mathrm{ml}$. Fig. (3) illustrated pomegranate peel beverages are good source of bioactive compounds which agrees with Nuamsetti et al. (2012) who reported that the phenolic content of hot aqueous extracts of the peels was $166.83 \mathrm{mg} / 100 \mathrm{ml}$.

DPPH radical scavenging activity assay assessed the ability of the beverage to donate hydrogen or to scavenge free radicals. DPPH radical is a stable free radical and when it reacts with an antioxidant compound which can donate hydrogen, it is reduced to diphenylpicrylhydrazine. Regarding antioxidant activity, results showed a positive relationship between pomegranate peel powder as a beverage and the antioxidant activity. The potent antioxidant activities of pomegranates are attributed to its polyphenols.

Table (4): Sensory Evaluation of pomegranate peel beverage.

\begin{tabular}{|c|c|c|c|c|c|c|}
\hline Samples & Taste (10) & Flavor (10) & Odor (10) & Color (10) & $\begin{array}{l}\text { After } \\
\text { taste (10) }\end{array}$ & $\begin{array}{l}\text { Overall } \\
\text { Acceptability } \\
\text { (10) }\end{array}$ \\
\hline $0.5 \%$ & $8.70 \pm 0.47^{b}$ & $9.14 \pm 0.39^{b}$ & $9.05 \pm 0.48^{a b}$ & $9.06 \pm 0.39^{a b}$ & $8.64 \pm 0.39^{b}$ & $8.87 \pm 0.56^{b}$ \\
\hline $1.0 \%$ & $9.23 \pm 0.52^{a}$ & $9.51 \pm 0.41^{a}$ & $9.45 \pm 0.33^{a}$ & $9.42 \pm 0.53^{a}$ & $9.26 \pm 0.46^{a}$ & $9.27 \pm 0.38^{\mathrm{a}}$ \\
\hline $1.5 \%$ & $9.34 \pm 0.56^{a}$ & $9.56 \pm 0.37^{a}$ & $9.49 \pm 0.32^{\mathrm{a}}$ & $9.52 \pm 0.46^{a}$ & $9.31 \pm 0.52^{a}$ & $9.35 \pm 0.34^{a}$ \\
\hline $2.0 \%$ & $8.75 \pm 0.45^{a b}$ & $9.25 \pm 0.46^{a}$ & $9.34 \pm 0.44^{\mathrm{a}}$ & $8.79 \pm 0.47^{b}$ & $8.85 \pm 0.57^{b}$ & $8.96 \pm 0.51^{a b}$ \\
\hline $2.5 \%$ & $6.48 \pm 0.69^{c}$ & $8.07 \pm 0.38^{c}$ & $8.61 \pm 0.36^{b}$ & $8.14 \pm 0.51^{c}$ & $7.82 \pm 0.35^{c}$ & $7.55 \pm 0.49^{c}$ \\
\hline
\end{tabular}



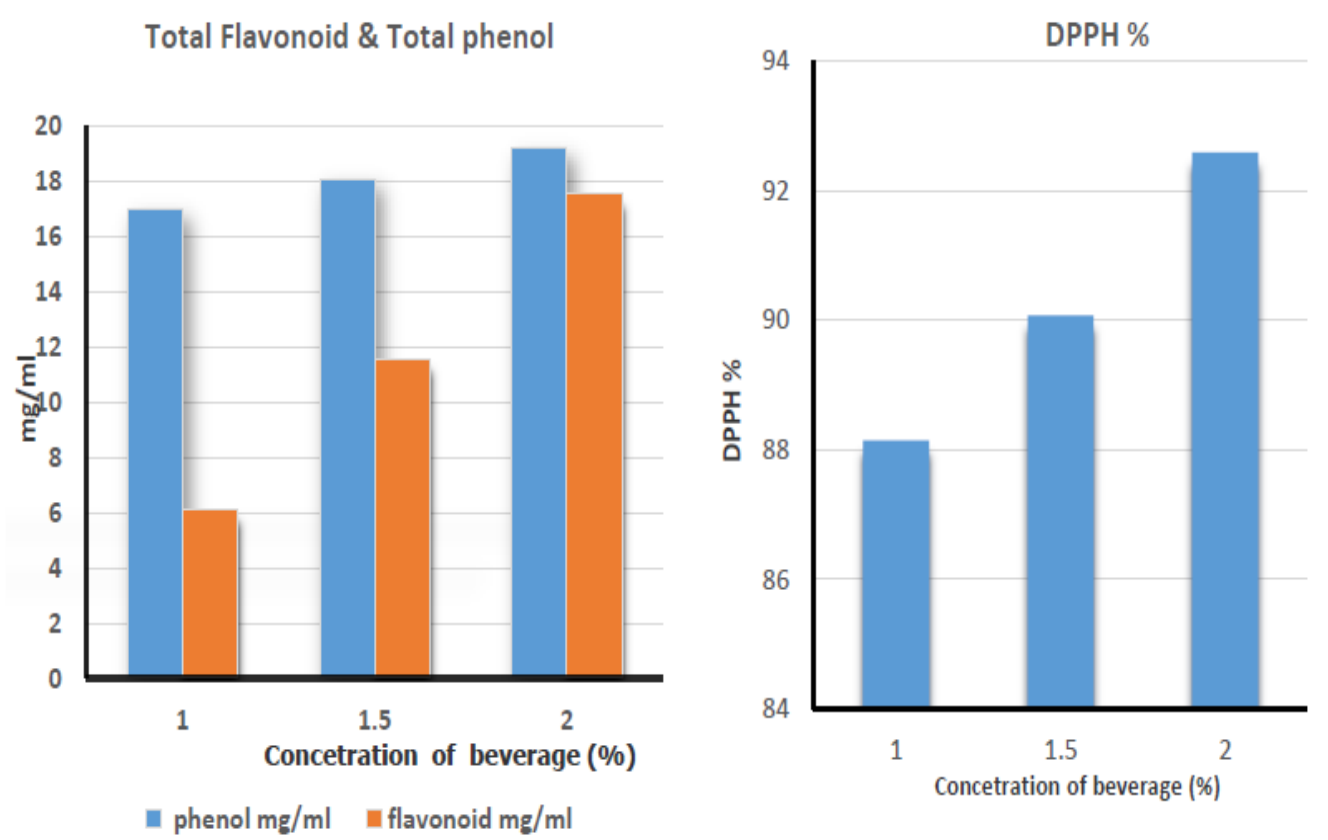

Fig (3): Total phenols and total flavonoids as bioactive compound content and antioxidant activity of PGP Beverage.

The antioxidant activity in the present study showed similar trend with those reported by Bharani and Namasivayam (2016).

\subsection{Identification and fractionation of phenols and flavonoids of pomegranate peel powder and its beverage.}

High-performance liquid chromatography (HPLC) was used for the identification and quantitative analysis of polyphenolic compounds of pomegranate peel. In Table (5) the current study several phenols were separated quantitatively. In general, the composition of polyphenolic substances in PGP was higher than that of PGP beverage. PGP had 7 components were most common types can be stated as Ellagic, Catechein, gallic, Chlorogenic, Epi-catechine, Protocatchoic and Caffeine with amounts of (1491.85, 531.55, 209.916, 187.35, 99.302, 68.014 and $56.63 \mathrm{mg} / 100 \mathrm{~g}$ ) which constituted about $95.9 \%$ of the total phenols. However, the phenolic compounds: caffeic acid, iso-ferulic, ferulic acid and coumarin were present as minor constituents. Thus, the presence of phenols confirms the antimicrobial activity of pomegranate, in agreement with (Gibbons, 2005) who successfully evaluated dietary polyphenols as chemopreventive and therapeutic agents to their direct antimicrobial action and antibiotic modulation activity.

Additionally, Yi et al. (2014) reported that this has been linked to their chemical structure and their ability to form complexes with bacterial membranes and proteins. Several studies have shown the antibacterial activity of polyphenols against H. pylori (Ankolekar et al., 2011). Besides, Elango et al. (2011) evaluated the anticarcinogenic activity of pomegranate peel extract against A549 tumor cells and confirmed that the actions was due to the presence of phenolic components which proposed the presence of high amount of Gallic acid with its anticarcinogenic activities. 
Table (5): HPLC analysis for Identification of phenols of pomegranate peel powder and its beverage.

\begin{tabular}{|l|l|l|}
\hline Phenols & $\begin{array}{l}\text { PGP } \\
(\mathrm{mg} / \mathbf{1 0 0 g})\end{array}$ & $\begin{array}{l}\text { PGP Beverage 2\% } \\
(\mathrm{mg} / \mathbf{1 0 0} \mathbf{~ m l})\end{array}$ \\
\hline Caffeine & $\mathbf{5 6 . 6 3}$ & $\mathbf{1 . 2 3 4}$ \\
\hline iso-feruilc & $\mathbf{4 . 4 8 8}$ & $\mathbf{0 . 1 0 6}$ \\
\hline Caffeic & 23.07 & $\mathbf{0 . 5 2 1}$ \\
\hline p- coumaric & $\mathbf{9 . 8 2}$ & $\mathbf{0 . 2 1 3}$ \\
\hline Ferulic & $\mathbf{2 2 . 8 6}$ & $\mathbf{0 . 5 0 9}$ \\
\hline Chlorogenic & 187.35 & $\mathbf{4 . 0 9 1}$ \\
\hline Epi-catechine & $\mathbf{9 9 . 3 0 2}$ & $\mathbf{2 . 1 5 7}$ \\
\hline Catechol & 138.42 & $\mathbf{3 . 9 4 8}$ \\
\hline Catechein & $\mathbf{5 3 1 . 5 5}$ & $\mathbf{9 . 9 7 9}$ \\
\hline Protocatchoic & $\mathbf{6 8 . 0 1 4}$ & $\mathbf{2 . 4 1 6}$ \\
\hline Ellagic & 1491.85 & $\mathbf{2 8 . 8 4 4}$ \\
\hline coumarin & 13.01 & $\mathbf{0 . 3 5 2}$ \\
\hline Gallic & 209.916 & $\mathbf{5 . 0 8 5}$ \\
\hline Total & 2756.964 & $\mathbf{5 9 . 4 5 5}$ \\
\hline
\end{tabular}

Meanwhile, in the present study several flavonoids have been separated quantitatively. Table (6) illustrated the most common types can be stated as Hesperidin, Hespertin, Naringin, Rutin and Qurectrin with amounts 121.13, 44.267, $72.26,56.95$ and $28.21 \mathrm{mg} / 100 \mathrm{~g}$ respectively.

Table (6): HPLC analysis for identification of flavonoid of pomegranate peel powder and its beverage.

\begin{tabular}{|l|c|c|}
\hline Flavonoid & $\begin{array}{c}\text { PGP } \\
(\mathbf{m g} / \mathbf{1 0 0 g})\end{array}$ & $\begin{array}{c}\text { PGP Beverage } \\
\text { 2\% } \\
(\mathbf{m g} / \mathbf{1 0 0} \mathbf{~ m l})\end{array}$ \\
\hline Rhamentin & $\mathbf{5 . 2 6}$ & $\mathbf{0 . 7 9 9 2}$ \\
\hline Kampferol & $\mathbf{3 . 0 0}$ & $\mathbf{0 . 6 8 4}$ \\
\hline Hespertin & $\mathbf{4 4 . 2 6 7}$ & $\mathbf{2 . 3 3 5}$ \\
\hline Narengenin & $\mathbf{3 . 0 3}$ & $\mathbf{0 . 1 4 3}$ \\
\hline Qurectin & $\mathbf{3 . 6 5}$ & $\mathbf{0 . 1 5 7}$ \\
\hline Qurectrin & $\mathbf{2 8 . 2 1}$ & $\mathbf{1 . 0 3 3}$ \\
\hline Rutin & $\mathbf{5 6 . 9 5}$ & $\mathbf{3 . 7 2 7}$ \\
\hline Hesperidin & $\mathbf{1 2 1 . 1 3}$ & $\mathbf{6 . 6 3 4}$ \\
\hline Naringin & $\mathbf{7 2 . 2 6}$ & $\mathbf{4 . 0 8 3}$ \\
\hline Apigenin & $\mathbf{3 . 0 0}$ & $\mathbf{0 . 1 5 1}$ \\
\hline Total & $\mathbf{3 3 5 . 1}$ & $\mathbf{2 7 . 7 4 6}$ \\
\hline
\end{tabular}

Ferrazzano et al. (2011) reported many natural flavonoids as possessing various pharmacological properties. In addition to their antioxidant activity, flavonoids also show good antibacterial activity against both gram-positive and gram-negative isolates (Coppo and Marchese, 2014). Some researchers established that flavonoids particularly quercetin and its glycoside derivatives are the main compounds responsible for the antioxidant properties (Silvia et al., 2011). These classes of compounds possess a broad spectrum of biological activities including radical scavenging properties (Balasnram et al., 2006). In general, this point needs further research to elucidate the effect of individual phenolic compound and its concentration on the antioxidant phenomenon.

\section{Conclusion}

The findings of the present study suggest that pomegranate peels and its beverage are rich in polyphenolic content and antioxidant activity with antibacterial alternatives as a better substitute in place of synthetic antioxidants and antibiotics. In addition, bioactive compounds from pomegranate peel beverage can be used as a dietary adjuvant for controlling human infections with Campylobacter. 


\section{REFERENCES}

A.O.A.C. (2005). Official Methods of Analysis, Association of Official Analytical Chemists $\left(18^{\text {th }}\right.$ ed.) Washington, DC., USA.

Abhijeet P., Jui V. J., Aditi A. P., Richa N. J. and Kuchekar B. S. (2010). Formulation and evaluation of anti-bacterial and anti-fungal activity of a herbal ointment containing Aloe-vera, Azadirachta indica and Curcuma- longa. J. Chem. Pharm. Res., 2 (3):182-186.

Ankolekar C., Johnson D., Pinto M. d. S., Johnson K., Labbe R., Shetty K. (2011). Inhibitory potential of tea polyphenolics and influence of extraction time against Helicobacter pylori and lack of inhibition of beneficial lactic acid bacteria. J. Med. Food, 14 (11): 1321-1329.

Balasnram N., Sundram K. and Samman S. (2006). Phenolic compounds in plant and agri-industrial byproducts: antioxidant activity, occurrence and potential uses. Food Chem., 99: 191-203

Bharani R.S A. and Namasivayam S. R. (2016). Pomegranate (Punica granatum 1.) peel extract-a study on a potential source of pharmacological activities Int'l. J. Pharm. Bio. Sci., 7 (4): (B) 282-290.

Borges, A., Ferreira C., Saavedra J. M. and Simo es M. (2013). Antibacterial activity and mode of action of ferulic and gallic acids against pathogenic bacteria. Microb. Drug Resist., 19 (4):256-65

Braga L. C, Shupp J. W., Cummings C., Jett M., Takahashi J. A. and Carmo L. S. (2005). Pomegranate extract inhibits Staphylococcus aureus growth and subsequent enterotoxin production. J. Ethnopharmacol., 4;96:335-9.

Brand-Williams W., Cuvelier M. E., and Berset C. (1995). Use of a free radical method to evaluate antioxidant activity, Lebensm.Wiss. Tech., 28:25-30.

Brauner A., Lena B., Frisan T., Thelestam M. and Ekbom A. (2010). Is there a risk of cancer development after Campylobacter infection? Sca. J. Gastroenterol., 45: 893-897.

Coppo E. and Marchese A. (2014). Antibacterial activity of polyphenols? Curr. Pharm. Biotech., 15 (4), 380-390.

Elango S., Balwas R., and Vijaya P. V. (2011). Gallic acid isolated from pomegranate peel extract induces reactive oxygen species mediated apoptosis in A549 cell line. J. Cancer Therapy, 2, 638-645

Ferrazzano G. F., Amato I., Ingenito A., Zarrelli A., Pinto G. and Pollio A. (2011). Plant polyphenols and their anti-cariogenic properties: a review. Molecules, 16 (2): 1486-1507.

Gibbons, S. (2005). Plants as a source of bacterial resistance modulators and anti-infective agents. Phytochem. Rev., 4 (1): 63-78.

Goupy P., Hugues M. and Boivin. P. (1999). Antioxidant composition and activity of barley (Hordeum vulgare) and malt extracts and of isolated phenolic compounds. J. Sci. Food Agric., 79: 1625-1634.

Guerra L., Guidi R. and Frisan T. (2011). Do bacterial genotoxins contribute to chronic inflammation, genomic instability, and tumor progression. FEBS J. 278:4577-458.

He Y. P., and Chen C. Y. (2010). Quantitative analysis of viable, stressed and dead cells of Campylobacter jejuni strain 81-176. Food Micro., 27:439-446

Jahfar M., Vijayan K. K. and Azadi P. (2003). Studies on a polysaccharide from the fruit rind of Punica granatum. Res. J. Chem and Environ., 7:43-50.

Kasimsetty S. G., Bialonska D., Reddy M. K., Ma G., Khan S. I. and Ferreira D. (2010). Colon cancer chemopreventive activities of pomegranate ellagitannins and urolithins. J. Agric. and Food Chem., 58, (4):2180-2187.

Khan S. and Hanee S. (2011). Antibacterial properties of Punica granatum peels. Int'l. J. App. Pharma. Res., 2 (3):102-116.

Klancnik A., Mozina S. S., and Zhang Q. (2012). Anti-Campylobactera ctivities and resistance mechanisms of natural phenolic compounds in Campylobacter. PLOS ONE. 7:e51800.0.1371/journal.pone.0051800

Kossah R., Zhang H. and Chen W. (2011). Antimicrobial and antioxidant activities of Chinese sumac (Rhus typhina) fruit extract. Food Control, 22, 128-132.

Kusters J. G., van Vliet A. H., Kuipers E. J. (2006). Pathogenesis of Helicobacter pylori infection. Clin Microbiol Rev., 19: 449-490.

Larrosa M., Tomas-Barberan, F. A., and Espin, J. C. (2006). The dietary hydrolysable tanin punicalagin releases ellagic acid that 
induces apoptosis in human colon adenocarcinoma Caco- 2 cells by using the mitochondrial pathway. J. Nutr. Bioch. 17, (9): 611-625.

Li Y., Guo C., Yang J., Wei J., Xu J. and Cheng S. (2006). Evaluation of antioxidant properties of pomegranate peel extract in comparison with pomegranate pulp extract. Food Chem., 96(2): 254-260.

Mattila P., Astola J. and Kumpulainen J. (2000). Determination of flavonoids in plant material by HPLC with diode-array and electro-array detections. J Agric. Food Chem., 48: 5834-5841.

Mirghani M. E. S., Al-Mamun, A. Daoud, J. I. and Mustafa, S. M. (2012). Processing of date palm kernel (DPk) for production of edible jam. Aust. J. of Bas. App. Sci., 6: 22-29.

Moghaddam M. N. (2011). In vitro inhibition of Helicobacter pylori by some spices and medicinal plants used in Iran .Glob. J. Pharm, 5 (3): 176-180.

Nuamsetti T., Dechayuenyong P., and Tantipaibulvut S. (2012). Antibacterial activity of pomegranate fruit peels and arils. Science Asia, 38 319-322

Rabah C., Aman B., Khadidja B. and Hamida N. (2015). Bactericidal effect of aqueous extracts of the bark of the pomegranate (Punica granatum L.) on bacteria Europ. J. Molec. Biotech., 7:14-11,

Rather R. A., Swetha C. and Rajagopal K. (2010). Screening of peel extracts as antioxidants, anticancer agents and antimicrobials. Advances in Biores., 1.(1): 29-33.

S.A.S. (1996). Statistical Analysis System (SAS). User's guide, Institute, Carry, NC., U S A.

Sadik M. S. and Asker M. M. S. (2014): Antioxidant and antitumor activities of Pomegranate (Punica granatum) peel extracts. W. J. of Pharma. Sci., (11): 14411445

Sayed-Ahmed, E. F. (2014). Evaluation of pomegranate peel fortified pan bread on body weight loss. Int'l. J. Nutr. Food Sci.; 3(5): 411-420

Senadeera W., Bhandari B. R., Young G. and Wijesinghe B. (2003). Influence of shapes of selected vegetable materials on drying kinetics during fluidized bed drying. J. Food Eng., 58 (3) 277-283.
Silvia E. M., Solange I. M., Martinez-Avila G., Montanez-Saenz J., Aguilar C. N. and Teixeira J. A. (2011). Bioactive phenolic compounds: Production and extraction by solid-state fermentation. A Review. Biotechnol. Adv., 29:365-373.

Singh S, Immanuel G. (2014). Extraction of antioxidants from fruit peels and its utilization in paneer. J. Food. Process. Tech. 5:349.

Singleton V. L., Orthofer R. and Lamuela Raventos R. M. (1999). Analysis of total phenols and other oxidation substrates and antioxidations by mean of Folin-Ciocateu reagent. Methods. Enzym., 299:152-178.

Sun Hee M. , Jae Hoon Lee, Kee-Tae Kim, YongSun P., Seung-Yeol N., Dong Uk A. and Hyun-Dong P. (2013). Antimicrobial effect of 7-O-butylnaringenin, a novel flavonoid, and various natural flavonoids against Helicobacter pylori strains. Int'l. J. Environ. Res., Public Health, 10(11): 5459-5469

Vaishnavi C., Kaur S. and Kaur M. (2007). Bactericidal activity of kitchen spices and condiments on enteropathogens. Nat. Prod. Radia., 6:40-45.

Valgas C., De Souza S. M. and Smânia E. F. A. (2007). Screening methods to determine antibacterial activity of natural products. Braz. J. Microbiol., 38:369-380.

Vicinanza R., Zhang Y., Henning S. M., and Heber D. (2013). Pomegranate juice metabolites, ellagic acid and urolithin a, synergistically inhibit androgenindependent prostate cancer cell growth via distinct effects on cell cycle control and apoptosis. J. Evid. Based Complemen. Altern. Med. Vol. Article ID 247504, 1-12.

Yi S., Wang W., Bai F., Zhu J., Li J. and Li X., (2014). Antimicrobial effect and membrane-active mechanism of tea polyphenols against Serratia marcescens. World J. Microbiol. Biotechnol., 30 (2), 451-460.

Zhishen J., Mengcheng T. and Jianming W. (1999). The determination of flavonoid contents in mulberry and their scavenging effects on superoxides radicals. Food Chem., 64:555-559. 


\section{تقييم قشر الرمان ومشروبه كمضاد للبكتريا ومضاد للسرطان \\ ابتهال العدوى الخولاني \\ قسم بحوث الاغذية الخاصة ـ معهد بحوث تكنولوجيا الاغذية ـ مركز البحوث الزراعية ـ الجيزةـ مصر}

ملخص الهن

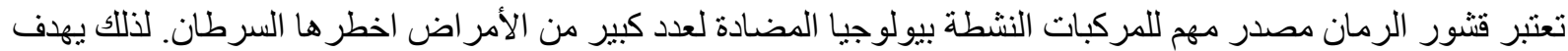

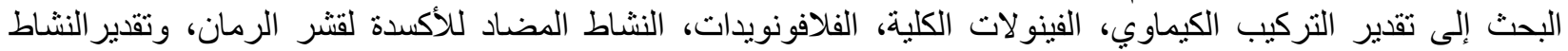

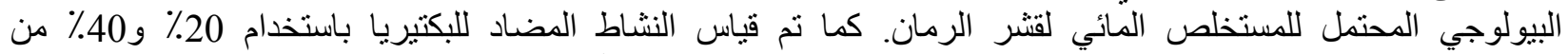

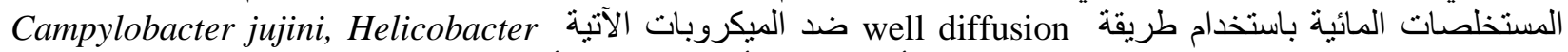

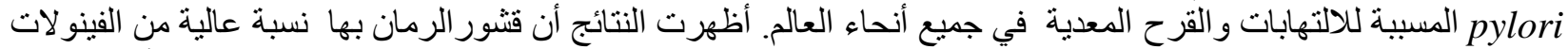
الكلية (198.33 mg Gallic acid/gm و الفلافونويدات الكلية (46.86 mg Quercetin/gm) مع نشاط مضاد للأكسدة عالية

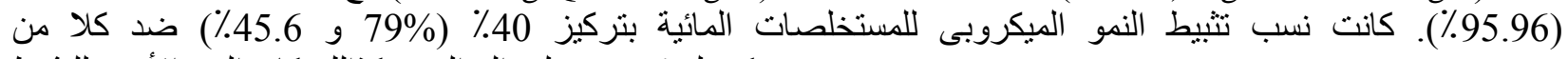
مelicobacter pylori , Campylobacter jujini

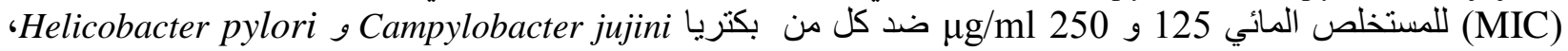

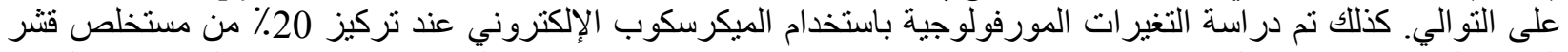
الرمان المائي (PGPa) على ميكروب Campylobacter jujini حيث اظهرت نتيجة الفحص تجزئة و استطالة ونوسيع الخلايا البكتيرية.

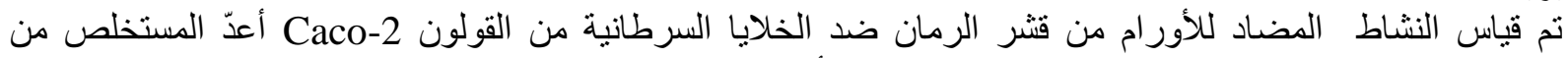
تركيزات مختلفة وتبين ان النشاط

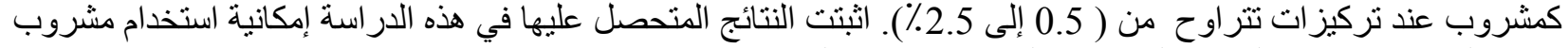

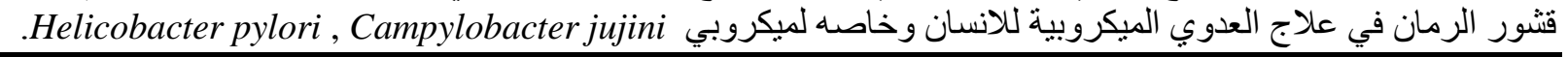

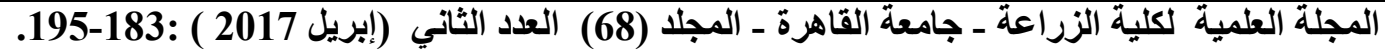

